Systemy Logistyczne Wojsk nr 50/2019

\title{
SUPPORT FOR OPTIMIZATION OF PALLETIZATION AND LOADING WITH USE OF CAPE PACK SOFTWARE
}

\author{
Małgorzata GRZELAK \\ malgorzata.grzelak@wat.edu.pl \\ https://orcid.org/0000-0001-6296-7098 \\ Military University of Technology \\ Faculty of Logistics \\ Institute of Logistics
}

\begin{abstract}
The aim of the article is to present the possibilities of using the CapePack computer software to support the planning of palletizing and loading in enterprises, as well as discussing the basic elements of the transport process and the conditions of forming the loading units and their main features. In addition, the paper describes the individual modules of the CapePack program with the possibilities of their use, and also presents its practical application to planning the delivery of combat and material resources during military exercises.
\end{abstract}

Keywords: cargo technologies, transport process, loading planning, optimization of surface use.

\section{INTRODUCTION}

Effective and efficient organization of transport processes has a direct impact on the proper functioning of enterprises and on the reduction of operating costs, but above all on increasing the level of service, which means timely and proper delivery of products to clients in accordance with their needs. Nowadays, where the time of order fulfillment plays a key role, it is important to have appropriate tools supporting decision making activities related to transport processes.

The purpose of the considerations is to present the possibility of supporting the implementation of transport tasks by optimizing the palletization and loading of transport means using the software of the Cape Pack by DM Systems.

\section{ORGANIZATION OF TRANSPORT PROCESSES IN THE ASPECT OF LOADING WORK}

The basic function of transport is to transport people or material goods from the point of production to destination according to the client's requirements. The transport process is defined as a series of specific activities coordinated with each other as a result of which the cargo will be delivered to the recipient. It includes the following activities:

- organizing including planning the route and creating the necessary documentation,

- executive related to the physical implementation of transport,

- commercial, which relate to the settlement of the costs of work performed. 
The above process consists of six basic stages, i.e. scheduling of cargo shipments, preparation of goods, organization of transport, physical movement of goods, legal and financial services for the operation being performed, and analysis of costs and quality of the transport process.

Inextricably linked to the transport process are cargo operations, on which the safety of transported cargo, road traffic, rolling stock used to carry out the transport and employees involved in the implementation of the above operations depend. Proper implementation of cargo operations significantly affects the technical condition of vehicles, which should be maintained in constant technical readiness and efficiency (Borucka, 2018, 3-19).

\section{BASIC ELEMENTS OF ORGANIZATION OF LOAD ACTIVITIES}

Forming of loads (in relation to transport) means a set of activities whose purpose is to prepare for transport both loose items, in unit and collective packaging, while ensuring rational use of the means of transport and the available load area. To enable the goods to be transported efficiently, packaging is used, whose primary role is to protect the transported goods against damage or negative impact on the environment.

Optimization of the use of the load area is ensured by the appropriate formation of loading units. The following study presents the possibilities of using the CapePack software to support packaging design, assemble pallet load units and develop loading plans, in order to make the best use of transport means in terms of their correct use (Borucka, 2018, 1073-1082), traffic safety (Świderski $\mathrm{i}$ in., 2018, 92-97) and minimization of operating costs, as well as the duration of operations.

Load units are used to determine the quantity of goods put together, using transport devices and auxiliary binders, in a way that guarantees durability of shape, dimensions and content during flow through the transport chain from the place of their assembly to unloading. It is characterized by enabling the mechanization of reloading along the entire flow path while maintaining the basic safety parameters. The correct combination of loading units is guaranteed by:

- selection of a suitable device, corresponding to the natural, technical and economic transport susceptibility of loads,

- the correct positioning of the load on or in the device,

- $\quad$ proper protection of goods against demolding during transport and storage.

Placing products should be characterized by the maximum use of the surface, capacity and load capacity of the load unit, with appropriate protection against demolding.

Depending on the technical means used, the following cargo units are distinguished:

- $\quad$ pallets, assembled with use of pallets,

- $\quad$ packets, formed with use of binders, 
- container,

- $\quad$ swap bodies,

- $\quad$ semi-trailers adapted for combined transport,

- semi-trailers of the bimodal system,

- transport containers.

In reference to the functionality of the analyzed computer software, which supports the planning of palletizing and containerization processes, only pallet and container load units have been considered.

A palette is defined as a load platform with one or two plates, one of which is used to start the load. The support plate is to be a plate or brackets and supports with a height reduced to a minimum, while being able to handle, transport, and pile up using forklifts. They are used to transport goods in packaging and in bulk. In literature, we distinguish the division of pallets according to the following criteria:

- in terms of the construction form:

○ flat one-plate or two-plate: two or four-part,

$\circ$ box pallets,

○ pillar pallets,

- flat with extensions,

- special ones,

- in terms of purpose:

○ reusable,

- disposable.

It is assumed that pallet load units should have a cuboidal shape with a load not protruding beyond the outline of the pallet. On the other hand, binding agents, e.g. heat-shrinkable foil, are used for their stabilization.

A load container is defined as a transport equipment unit characterized by specific technical characteristics and strength allowing multiple use. It has a special construction that ensures: the carriage of loads with one or more types of transport without the need to reload the goods themselves, ease of reloading to another means of transport and a capacity of not less than $1 \mathrm{~m}^{3}$.

In terms of size, containers are divided into:

- $\quad$ small with a gross weight less than $2500 \mathrm{~kg}$;

- $\quad$ average with a gross weight between $2,500 \mathrm{~kg}$ and $10,000 \mathrm{~kg}$;

- $\quad$ large with a gross weight above $10,000 \mathrm{~kg}$. 
During the transport process, the cargo is subject to mechanical hazards resulting from the traffic on the roads. The use of the above packages is aimed at minimizing the effects of these hazards and the correct operation of transport means used for transport. In addition, it supports the processes of tracking the flow of resources in transport chains, e.g. using RFID technology (Waśniewski, 2011, 23-233).

\section{OPTIMIZATION OF PALLETIZATION AND CONTAINERIZATION IN TRANSPORT PROCESSES}

Currently, time is one of the main parameters of the competitiveness of entrepreneurs. They often rely on forecasts of market demand, and customers increasingly choose suppliers offering the shortest possible time of order completion (Mitkow, 2018, p. 501-526). In connection with the above, it is extremely important to shorten the time of organizational operations in the transport process. One of them is planning the formation of loads on pallets and in transport means. The aim is to minimize the duration of the above action and to maximize the use of means of transport (including containers as a transport packaging) in order to deliver the largest number of loads and reduce delivery costs.

Decision making in the palletizing area can be supported using the Cape Pack software, which can be applied at any stage of the process, from the design of finished product packaging to the final placing of the load on the pallet. The program consists of modular packages that allow you to determine the best sizes of products (at the design stage in production companies) and dimensions of packaging to develop the optimal arrangement of product layers and their placement on the pallet to make the best use of the transport device volume.

The use of the above tool enables optimization of product sizes, designing new dimensions of packaging, maximizing the use of pallets and, as a consequence, reducing transport costs by reducing the number of transport means, which further affects the reduction of carbon dioxide and environmental protection (Mikosz, 2008, 1-12). The basic software interface is shown in Figure 1. 


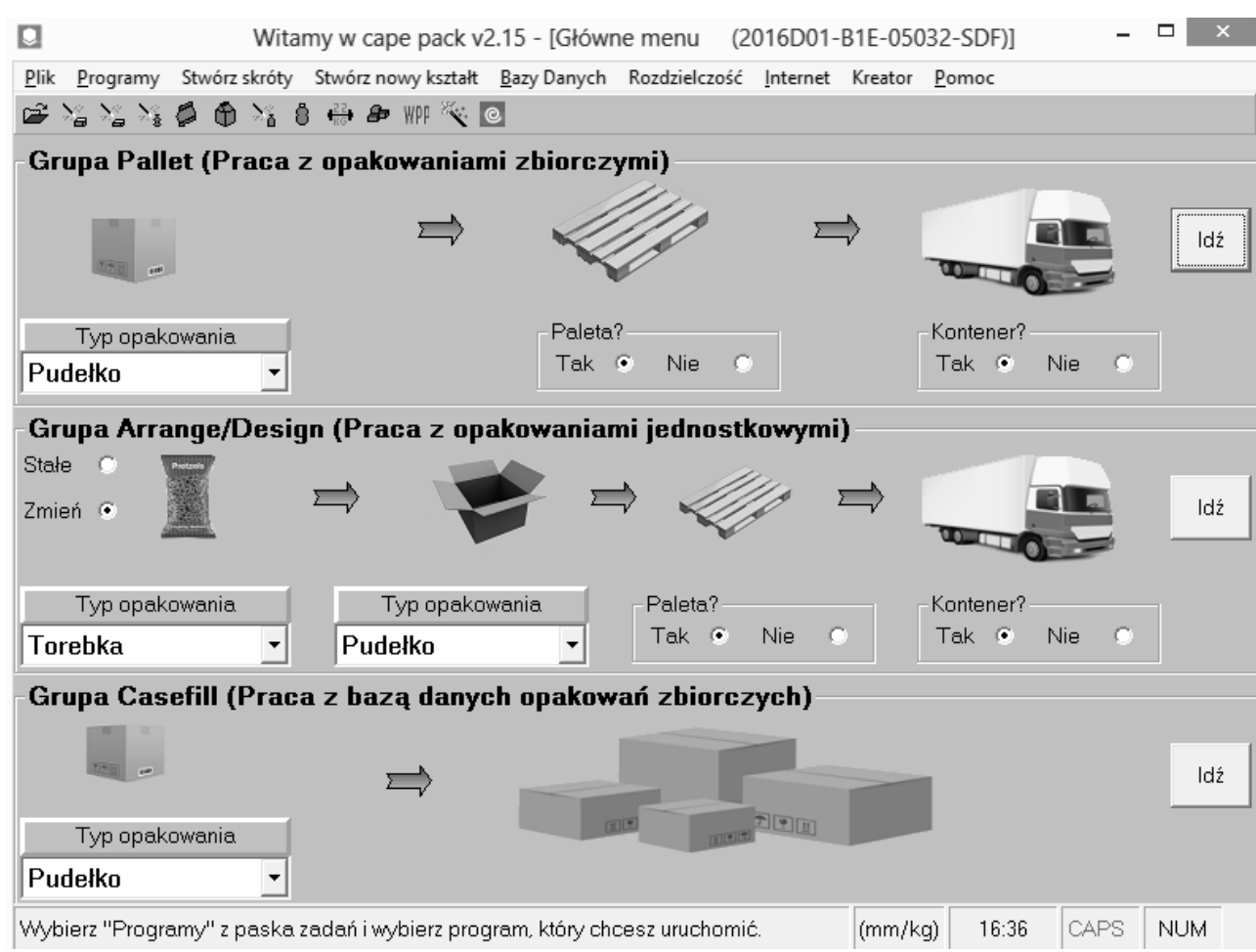

Fig. 1. Interface of CapePack software

Source: Own elaboration.

The program is divided into three main modules: pallet, arrange and design and additional accessories, i.e. display pallet, casefill, KDF, FCA and durability. The basis of the program is the pallet group, which enables the calculation of pallet systems (based on a standardized transport equipment library or created for the client's needs) consisting of collective packaging with known dimensions on a standard pallet and means of transport. The development of the loading plan consists of three stages (Fig. 2):

- selection of the existing packaging in the database,

- indication of the pallet as the carrier of the unit load,

- selection of the transport means. 


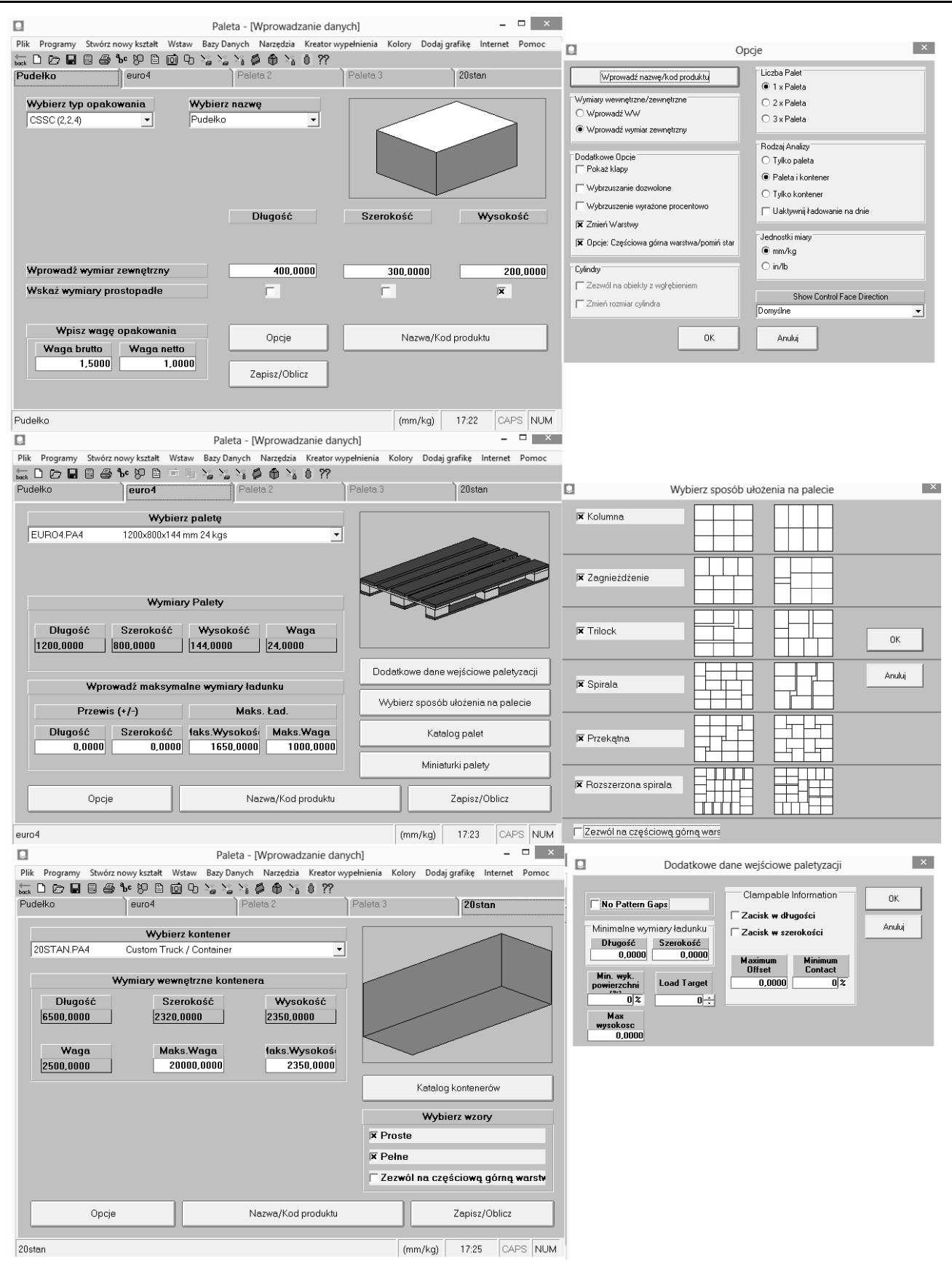

Fig. 2. Stages of palletizing planning in pallet module Source: Own elaboration.

The module enables to indicate basic calculation options, i.e. units of measure, type of load dimensions (external or internal), number of pallets used, type of analysis (only pallet or pallet with container) and allowing the possibility of bulging goods during the development of the loading plan. At the pallet selection stage, the planner can determine the desired way of packaging arrangement (e.g. column, nesting), as well as the minimum dimensions of the pallet load unit, maximum height, minimum use of space and load capacity. 


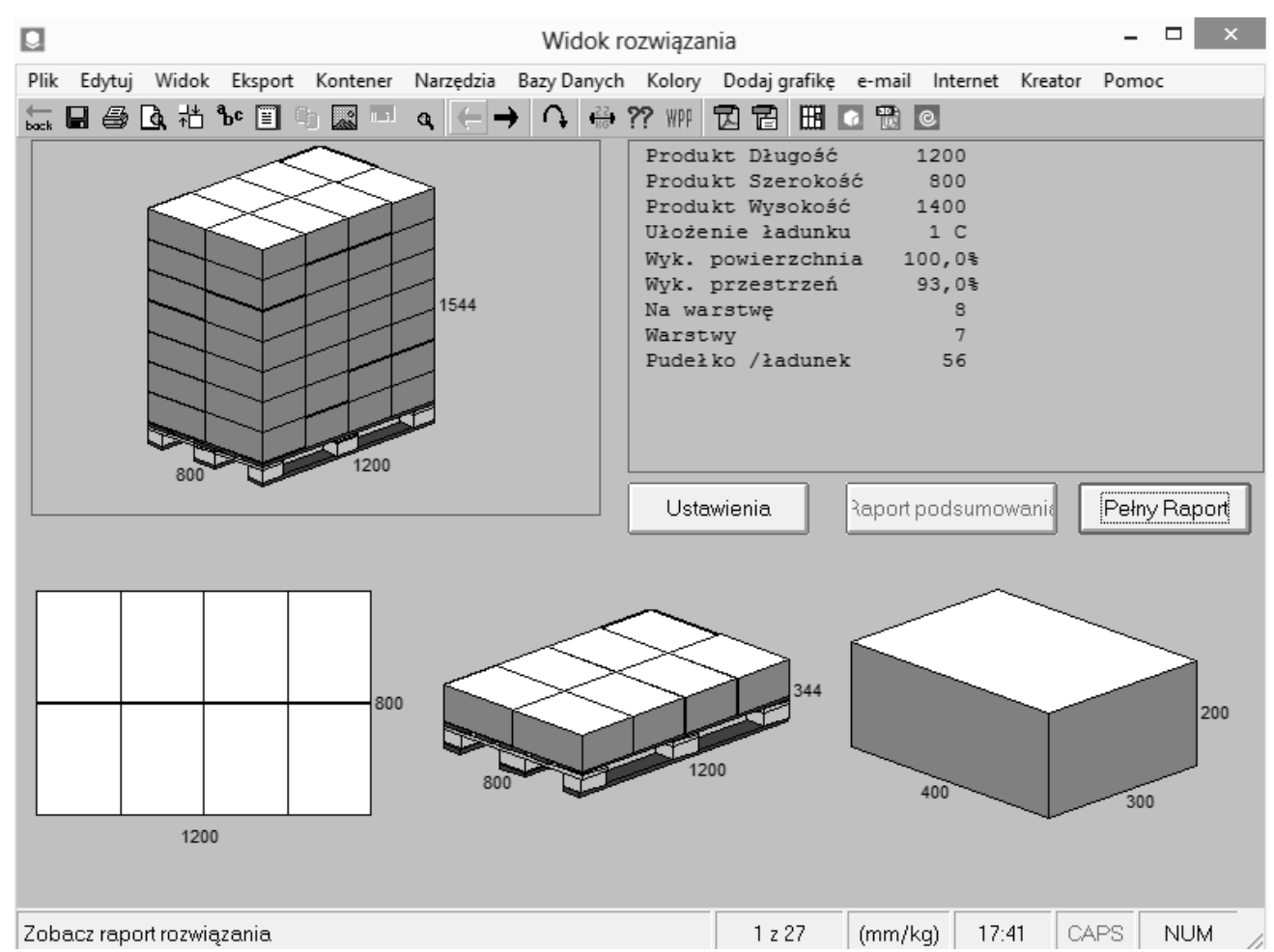

Fig. 3. Palletization report

Source: Own elaboration.

Finally, the program generates a report (Fig. 3), which contains information about possible load variants and their basic parameters, such as height, length, width and weight of the unit load, the way the packages are placed on the pallet and their number along with the visualization.

Another group of solutions is the arrange module, which is an extension of the pallet module with the possibility of optimizing the unit package in bulk packaging and further on the pallet and transport means, and the design module, which additionally enables modeling of individual packages by modifying the initial dimensions with deviations acceptable by the manufacturer, in order to maximize the number of packages on the pallet (Fig. 4). 


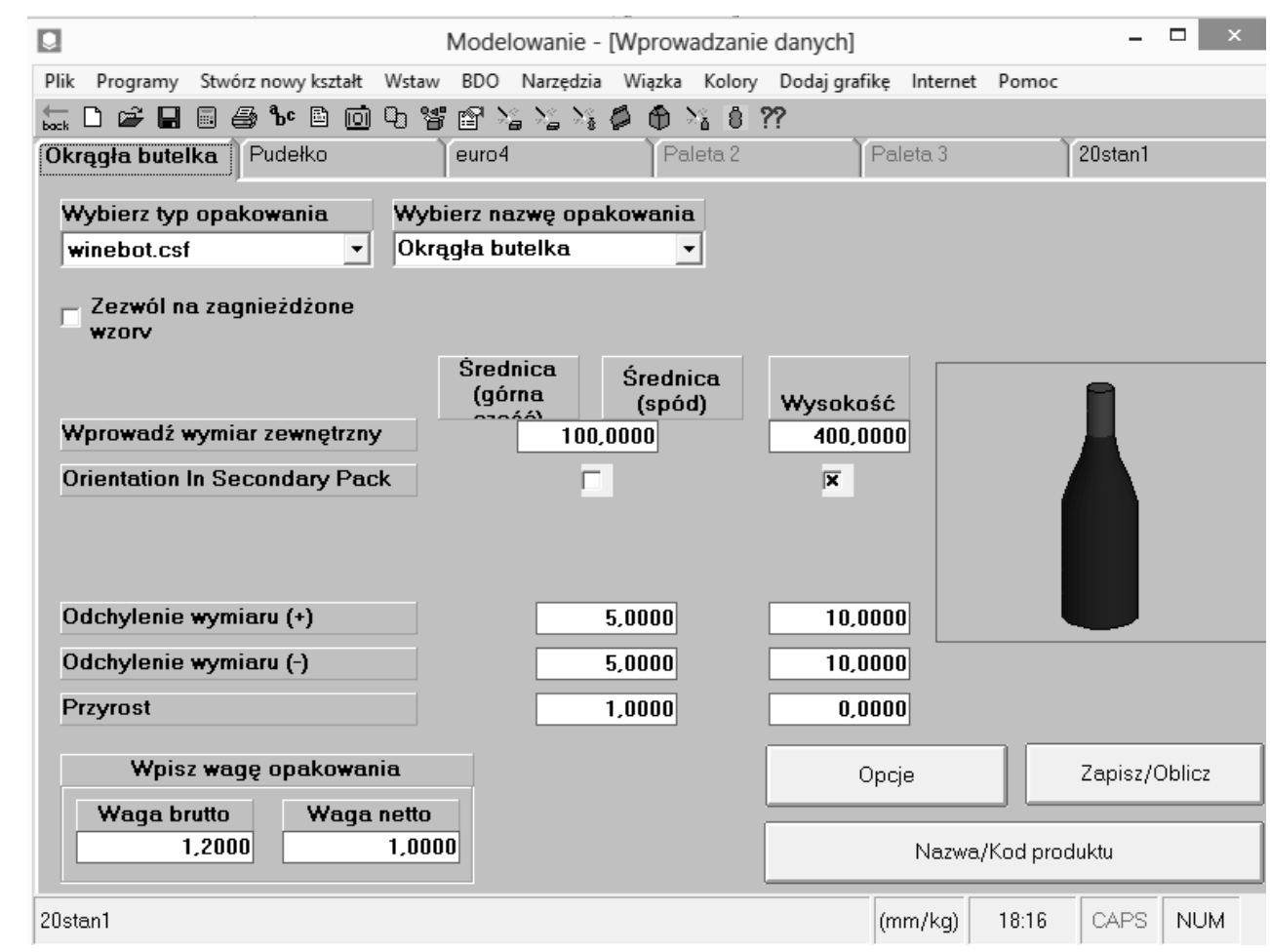

Fig. 4. Module arrange/design tab

Source: Own elaboration.

The planner can select a unit package from the base or create a new one based on data from the production department. By entering information into the system, it is possible to select the option allowing planning for the use of space with minimal deviations of the unit dimensions of products from the set ones. This is to check whether small changes can have a significant impact on the efficiency of transport processes by increasing the filling of the load space.

Figure No. 5 illustrates the comparison of pallet loading plans reports in two variants of unit packages, in the case of dimensions set at the entrance and the approach of using the surface with a minimum correction of the size of the bottle. Based on the report, it can be stated that the change in the size of the bottle does not have a significant impact on the load on the pallet (288 in both cases), only the dimensions of the load unit as a whole are variable (in the height range). In addition, the summary shows the scheme of loading the container for the individual units being formed. 


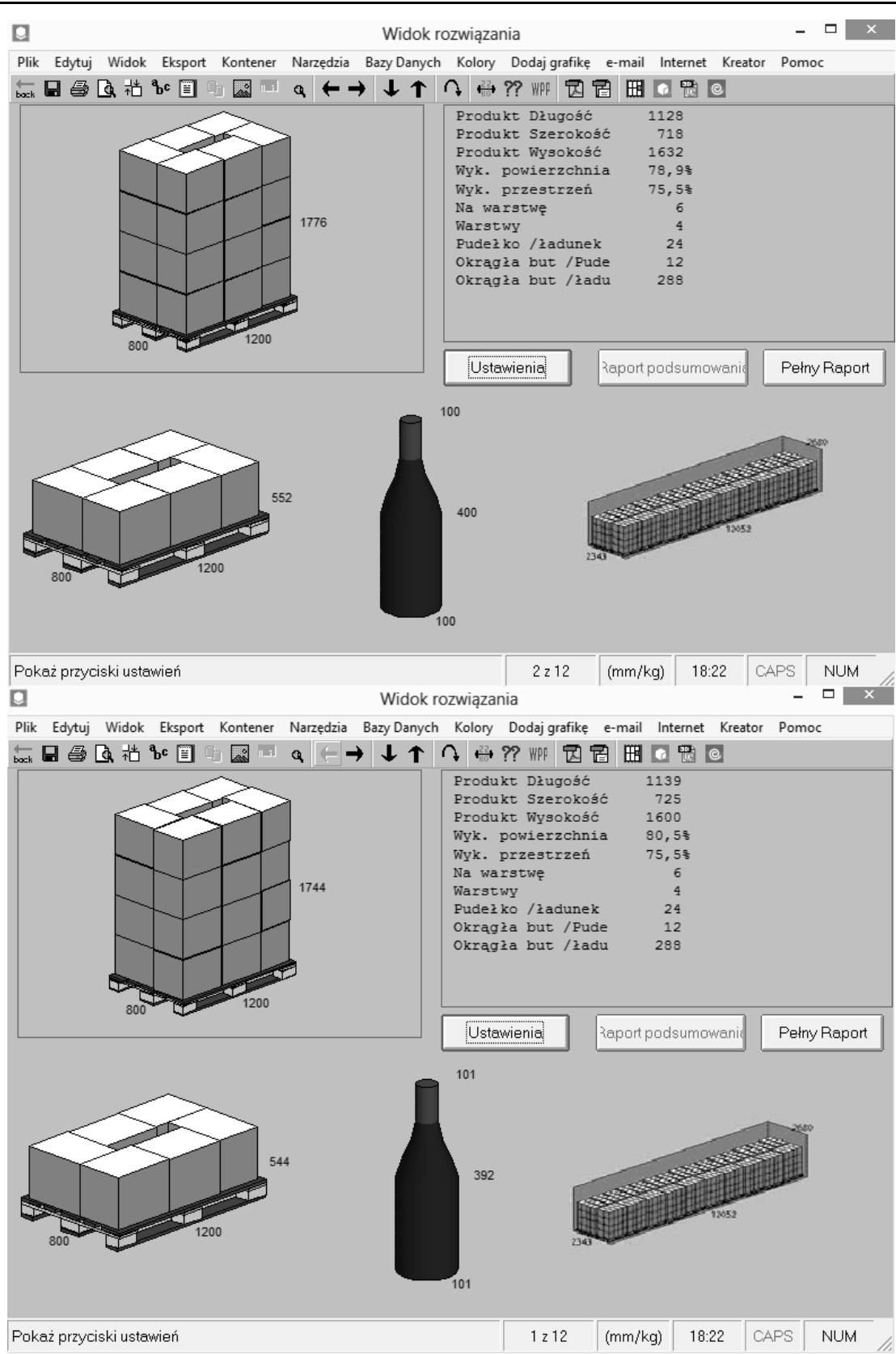

Fig. 5. Final pallet(ization) report in arrange/design module Source: Own elaboration.

The third group of solutions are modules with additional accessories:

- pallet display allowing calculation of both individual pallets and a whole group of goods with different dimensions and types of packaging, especially useful when delivering heterogeneous product groups,

- casefill allowing selection of the optimal packaging for unit products based on the available database, providing information which of them can accommodate the most of the indicated products and be most effectively used, 
- durability, which allows you to estimate the durability of packaging made of cardboard on the basis of a number of parameters, i.e. humidity, storage time or the number of graphics on the packaging.

The integration of the above presented solutions enables entrepreneurs to reduce costs by increasing the number of products on the pallet, saving working time and shortening the implementation of planning processes, immediately providing calculation results, generating and providing customers with reports on loading plans and minimizing the number of errors during the palletizing process.

\section{THE USE OF THE CAPE PACK SOFTWARE IN PLANNING THE CARRIAGE OF COMBAT RESOURCES FOR THE NEED FOR ARMED FORCES}

The presented software finds wide application in organizing transport processes in enterprises. It can also be used to support transport planning in state entities, including the Armed Forces, both at the level of the Military Economic Branches (Borucka, 2013, 39-48) while providing logistics support in the ongoing operation of troops, as well as by military units during preparation for the implementation of military exercises, both in peacetime, as well as during the delivery of combat and material resources during the crisis and war (Borucka, Wielgosik, 2016, 51-66). As there is freedom when it comes to transport means that are analyzed in terms of loading plans, it can be used to organize the flow of goods by road transport, but also when planning the transport of containers by rail or sea.

Below, there is an example of the use of ammunition planning software for subunits during exercises by vehicles that are equipped with them. For this purpose, the display pallet module was used. The planning process is initiated by introducing the assortment into the program together with the dimensions and types of individual ammunition packages, based on which the loading list is created (Fig. 6). 


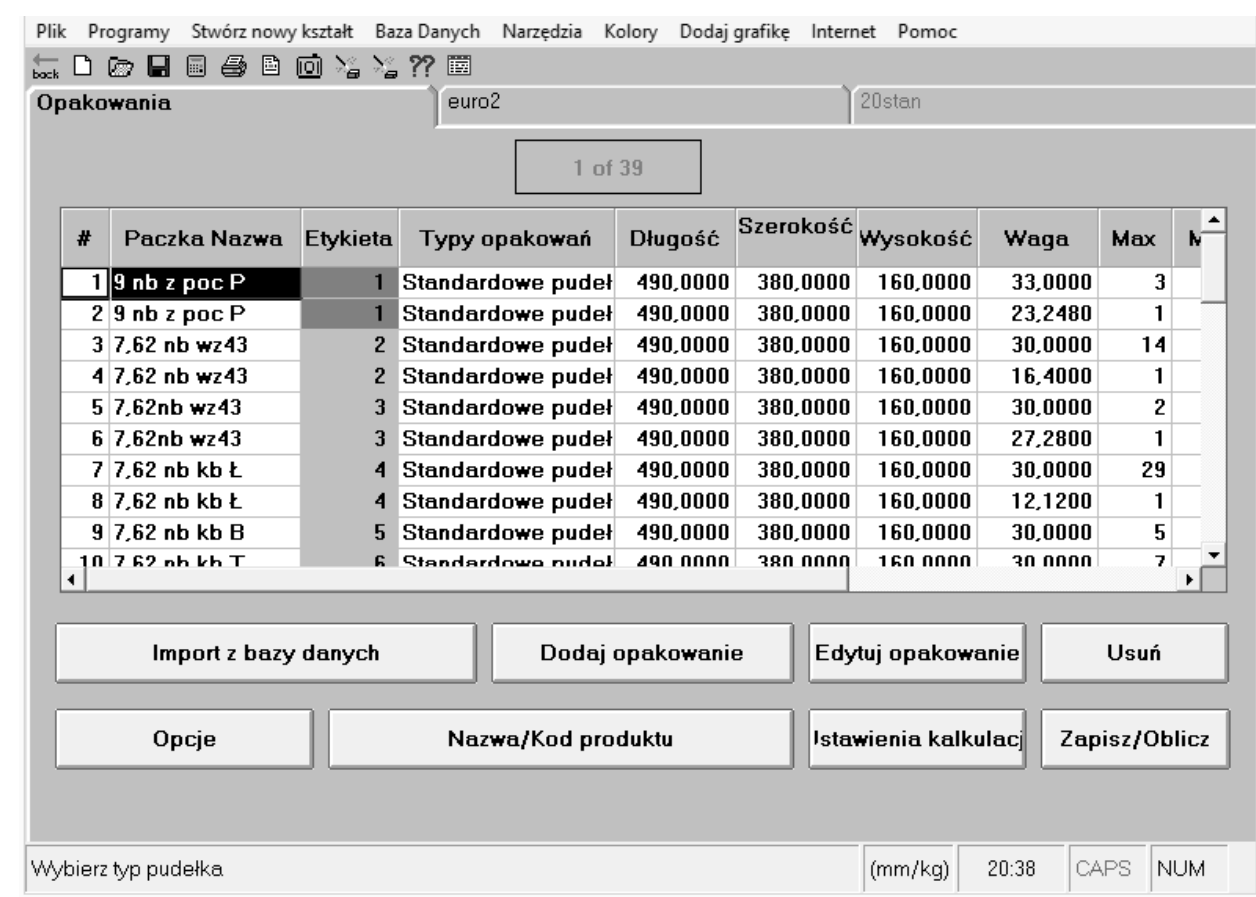

Fig. 6. Load list of combat and material resources transport Source: Own elaboration.

Next, carriers of loading units are defined, in the analyzed case they are standard EURO pallets, and a defined transport means is a Star 944 vehicle. On the basis of collected data, optimization is carried out in terms of maximum use of load space or number of packages in units and then a report is generated. In addition, the system provides information on how to place pallets on load boxes, ensuring optimal use of the surface (Fig. 7). 


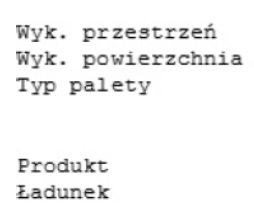

72,6 के
77,6 \%
EURO1
Diugość
980,0
1200,0

Szer.
760,0

\begin{tabular}{ccccc} 
& 20 & \multicolumn{2}{c}{ Opakowania / Eadunek } \\
Wysokość & Netto & Brutto & Rozmiar \\
$800,0 \mathrm{~mm}$ & - & $559,320 \mathrm{Kg}$ & $0,60 \mathrm{~m}^{\wedge} 3$ \\
$945,0 \mathrm{~mm}$ & 559,320 & $584,320 \mathrm{Kg}$ & $0,91 \mathrm{~m}^{\wedge} 3$
\end{tabular}
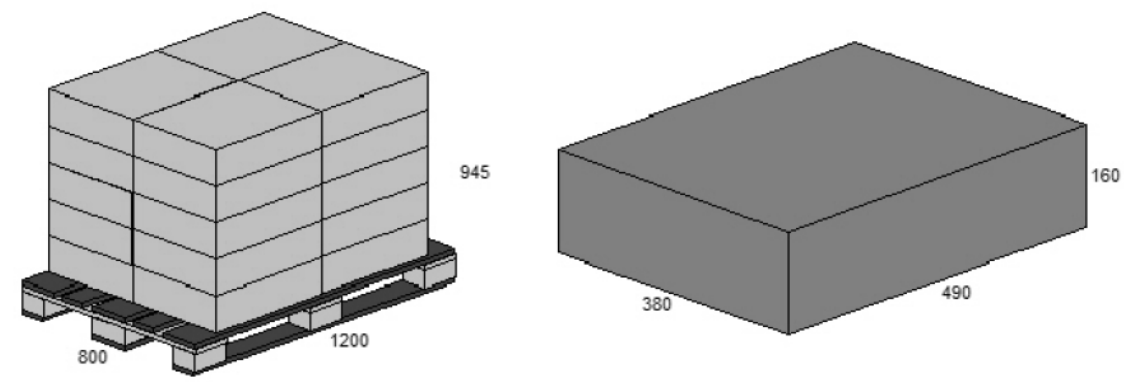

Package(s) Listing

\begin{tabular}{|c|c|c|c|c|c|c|c|c|c|c|}
\hline $\mathrm{Nr}$ & Nazwa & \begin{tabular}{|l|} 
\#/ \\
Eadun
\end{tabular} & $\begin{array}{l}\operatorname{Max} \\
k\end{array}$ & Min & $\begin{array}{l}\text { Opakow } \\
\text { Pakunk }\end{array}$ & & $\begin{array}{l}\text { Długość } \\
k\end{array}$ & Szerokos & Wysokośd & Waga \\
\hline 1 & $7,62 \mathrm{nb} \quad \mathrm{kb} \quad \mathrm{E}$ & 11 & 29 & - & 0 & 0 & 490,0 & 380,0 & 160,0 & 30,0 \\
\hline 2 & $7,62 \mathrm{nb} \quad \mathrm{kb} E$ & 1 & 1 & - & 0 & 0 & 490,0 & 380,0 & 160,0 & 12,1 \\
\hline 3 & $12,7 \mathrm{nb}$ B-32 & 7 & 7 & - & 0 & 0 & 490,0 & 380,0 & 160,0 & 30,0 \\
\hline 4 & $7,62 \times 51$ ppanc & 1 & 1 & - & 0 & 0 & 490,0 & 380,0 & 160,0 & 7,2 \\
\hline
\end{tabular}

\section{Description Listing}

\begin{tabular}{|c|c|c|c|c|c|}
\hline $\mathrm{Nr}$ & Nazwa & Opis & Etyki & Typ pudelka & \#/Eaduhel \\
\hline 1 & $7,62 \mathrm{nb} \mathrm{kb} E$ & $7,62 \mathrm{nb} \mathrm{kb}$ EPS & 4 & Standardowe pude: & 11 \\
\hline 2 & $7,62 \mathrm{nb} \mathrm{kb} E$ & 7,62 $\mathrm{nb} \mathrm{kb}$ EPS & 4 & Standardowe pude: & 1 \\
\hline 3 & $12,7 \mathrm{nb}$ B-32 & $12,7 \mathrm{nb} \quad \mathrm{B}-32$ & 11 & Standardowe pude: & 7 \\
\hline 4 & $7,62 \times 51$ ppanc & 7,62×51ppancAPI & 16 & Standardowe pude: & 1 \\
\hline
\end{tabular}

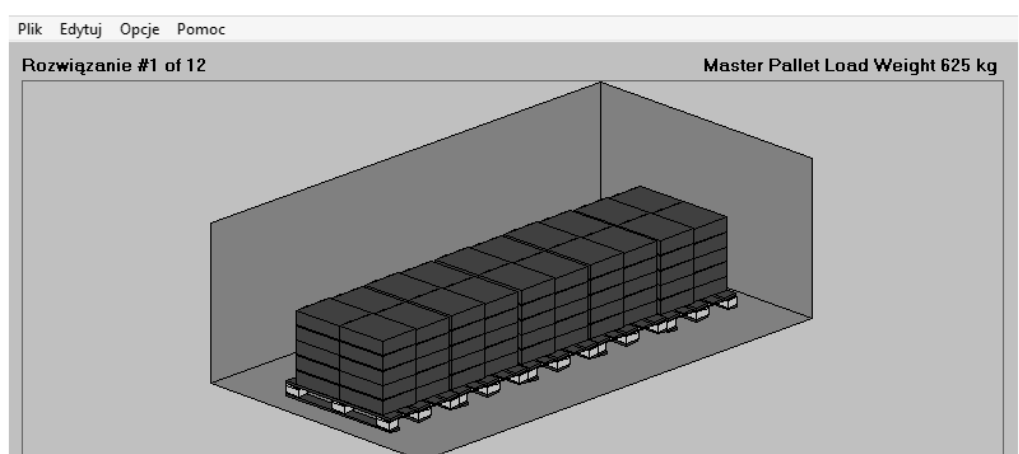

Fig. 7. The load report of combat and material resources transport Source: Own elaboration.

The report presents a loading list divided into individual pallet load units together with their arrangement, description and dimensions.

\section{CONCLUSION}

In conclusion, the aim of the article was to present the possibilities of using the CapePack computer software to support palletizing and loading planning in enterprises. The basic elements of the transport process as well as the conditions for forming the loading units and their main features were discussed. Individual modules of the program were characterized along with the possibilities of 
their use. In addition, it presented its practical application to planning the delivery of combat and material resources during military exercises.

The presented software can be used to plan the transport of any type of assortment in singleand heterogeneous pallet units, as well as "loose" based on any indicated cargo area, which can be load containers or boxes, both in private enterprises and state organizations. It enables cost reduction by increasing the number of products on the pallet, saving working time and shortening the implementation of planning processes, immediately providing calculation results, generating and providing customers with reports on loading plans and minimizing the number of errors during the palletizing process.

\section{REFERENCES}

[1] BoruCKA, A. (2013). Analiza polskiego transportu samochodowego. Systemy logistyczne wojsk, (39), $13-23$.

[2] BorUCKA, A. (2013). Funkcjonowanie wojskowych oddziałów gospodarczych w nowym systemie logistycznym sił zbrojnych. Logistyka, 6, 39-48.

[3] BorUCKA, A. (2018). Analysis of the effectiveness of selected demand forecasting models. Wspótczesna Gospodarka, 9(2), 41-55.

[4] BORUCKA, A. (2018). Application of ARIMA Models for the Analysis of Utilization Process of Military Technical Objects. Logistics and Transport, 37, 13-22.

[5] BORUCKA, A. (2018). Forecasting of fire risk with regard to readiness of rescue and fire-fighting vehicles. Interdisciplinary Management Research XIV', Croatia, 397-395.

[6] BORUCKA, A. (2018). Markov models in the analysis of the operation process of transport means. In Proceedings of the ICTTE International Journal For Traffic And Transport Engineering Conference, Belgrad (pp. 1073-1082).

[7] BoRUCKA, A. (2018). Model of the operation process of aircraft in the transport system. In Proceedings of the ICTTE International Journal For Traffic And Transport Engineering Conference, Serbia (pp. 22$30)$.

[8] BorucKA, A. (2018). Risk Analysis of Accidents in Poland Based on ARIMA Model. Transport Means, 162-166.

[9] BorUCKA, A. (2018). Three-state Markov model of using transport means. Business Logistics In Modern Management, 3-19.

[10] BoruCKA, A., \& Mikosz, B. (2008). Organizacja gospodarki odpadami w siłach zbrojnych na tle zmian militarnych i nowych wyzwań stawianych polskiej armii. Archiwum Gospodarki Odpadami i Ochrony Środowiska, 8, 1-12. 
[11] BoruCKA, A., \& MitKow, S. (2018). Mathematical model of travel times related to a transport congestion: an example of the capital city of Poland-Warsaw. Business Logistics In Modern Management, 501-526.

[12] JAKUBOwski, L. (2009). Technologia prac ładunkowych. Oficyna Wydawnicza Politechniki Warszawskiej.

[13] Michniewicz, I., \& Michniewicz, R. (2017). Jednoczesność korzystania z obiektu wodnego. Life and Movement, 1(11), 3-13.

[14] STARKOWSKI, D. (2017). Analiza procesu transportowego na przykładzie wybranego przedsiębiorstwa transportowo-spedycyjnego podczas przewozu truskawek. Część 3, Analiza logistyczna operacji przewozowej. Autobusy: technika, eksploatacja, systemy transportowe, 18, 1546-1551.

[15] ŚWiderski, A., \& BorUCKA, A. (2018). Mathematical Analysis of Factors Affecting the Road Safety in Selected Polish Region, Transport Means. In Proceedings of the 22nd International Scientific Conference part II, Lithuania (pp. 651-654).

[16] Świderski, A., BorUCKA, A., \& SKOCZYŃSKI, P. (2018, October). Characteristics and assessment of the road safety level in Poland with multiple regression model. In Transport Means', Proceedings of the 22nd International Scientific Conference, Part I, Lithuania (pp. 92-97).

[17] ŚWiderski, A., BorUCKA, A., JACYNA-GoŁdA, I., \& SzCZEPAŃSKi, E. (2019). Wear of brake system components in various operating conditions of vehicle in the transport company. Eksploatacja i Niezawodność, 1(21), 1-9. dx.doi.org/10.17531/ein.2019.1.1

[18] WAŚNIEWSKI, T., \& BORUCKA, A. (2011). Sieciowe rozwiązania w łańcuchu dostaw w oparciu o technologię radiowej identyfikacji towarów. Systemy Logistyczne Wojsk, (37), 235-245.

[19] WiElgOsIK, M., BORUCKA, A. (2016). Istota i znaczenie służby przygotowawczej i szkolenia rezerw, Systemy Logistyczne Wojsk, 45, 51-66.

[20] ŻUREK, J., ZIÓŁKOWSKI, J., \& BorUCKA, A. (2017). Application of Markov processes to the method for analysis of combat vehicle operation in the aspect of their availability and readiness. Safety and Reliability. Theory and Applications, ESREL, 2343-2352. 